\title{
Sanitary quality, occurrence and identification of Staphylococcus sp. in food services
}

\author{
Jozi Fagundes de Mello ${ }^{1}$, Laura Braga da Rocha ${ }^{2}$, Ester Souza Lopes ${ }^{3}$, \\ Jeverson Frazzon ${ }^{4}$, Marisa da Costa ${ }^{5}$ \\ ${ }^{1}$ Departamento de Nutrição, Faculdade de Nutrição, Universidade Federal de Pelotas, Pelotas, RS, Brazil. \\ ${ }^{2}$ Faculdade de Enfermagem, Universidade Federal do Rio Grande do Sul, Porto Alegre, RS, Brazil. \\ ${ }^{3}$ Programa de Pós-Graduação em Microbiologia Agrícola e do Ambiente, Instituto de Ciências Básicas da \\ Saúde, Universidade Federal do Rio Grande do Sul, Porto Alegre, RS, Brazil. \\ ${ }^{4}$ Departamento de Ciência dos Alimentos, Instituto de Ciência e Tecnologia de Alimentos, \\ Universidade Federal do Rio Grande do Sul, Porto Alegre, RS, Brazil. \\ ${ }^{5}$ Departamento de Microbiologia, Imunologia e Parasitologia, Instituto de Ciências Básicas da Saúde, \\ Universidade Federal do Rio Grande do Sul, Porto Alegre, RS, Brazil.
}

Submitted: January 22, 2013; Approved: March 14, 2014.

\begin{abstract}
bstract
Sanitary conditions are essential for the production of meals and control of the presence of pathogensis important to guarantee the health of customers. The aim of this study was to evaluate the sanitary quality of food services by checking the presence of thermotolerant coliforms, Staphylococcus sp. and evaluate the toxigenic potential from the latter. The analysis was performed on water, surfaces, equipment, ready-to-eat foods, hands and nasal cavity of handlers in seven food services. The water used in food services proved to be suitable for the production of meals. Most food, equipment and surfaces showed poor sanitary conditions due to the presence of thermotolerant coliforms (60.6\%). Twenty-six Staphylococcus species were identified from the 121 Staphylococcus isolates tested. Staphylococci coagulase-negative species were predominant in the foods, equipment and surfaces. In food handlers and foods, the predominant species was Staphylococcus epidermidis. Twelve different genotypes were found after PCR for the classical enterotoxin genes. The seb gene (19.8\%) was the most prevalent among all Staphylococcus sp. Both coagulase-positive and coagulasenegative Staphylococci showed some of the genes of the enterotoxins tested. We conclude that there are hygienic and sanitary deficiencies in the food services analyzed. Although coagulase-positive Staphylococci have not been present in foods there is a wide dispersion of enterotoxigenic coagulase-negative Staphylococci in the environment and in the foods analyzed, indicating a risk to consumer health.
\end{abstract}

Key words: food service, sanitary quality, Staphylococcus sp., Staphylococcal enterotoxin.

\section{Introduction}

The major objectives of food services are the production and distribution of foods with nutritional and sanitary quality. To achieve this quality, the World Health Organization recommends the adoption of good hygienic practices (Sambrook and Russel, 2001; WHO, 2012). Most outbreaks are caused by the ingestion of contaminated food after inadequate hygiene practices, production, storage and/or distribution (Losasso et al., 2012). The food services occupy the second position as a source of food intoxications/infections in Brazil, with Salmonella sp., Staphylococcus aureus and Escherichia coli being the main causative agents (USFDA, 2004; Brasil, 2011).

Outbreaks of Staphylococcus sp. are related to the production of one or more enterotoxins (SE), and SEA, SEB, SEC, SED and SEE are together responsible for $95 \%$ of the cases (Aragon et al., 2007; Pereira et al., 2009). Among these, SEB is the SE which has the highest thermo- 
stability and toxicity (Balaban and Rasooly, 2000). Although Staphylococcus aureus is the most evident species in food-borne outbreaks, coagulase-negative Staphylococci (CoNS) can also be producers of SE (André et al., 2008; Veras et al., 2008; Rall et al., 2010a; Oliveira et al., 2011).

Knowing and controlling the factors that can lead to the contamination of foods produced in a food service can minimize risks to the health of customers. This study aimed to evaluate the sanitary quality of food services, verify the presence of thermotolerant coliforms, Staphylococcus sp. and assessing the toxigenic potential from the latter.

\section{Materials and Methods}

\section{Food services and samples}

This study was conducted in seven large-scale food services (500 or more meals per day) and active in the city of Porto Alegre/Rio Grande do Sul - Brazil. Analyses were performed for thermotolerant coliforms and Staphylococcus sp. in: (I) ready-to-eat foods (raw salad, processed salad produced by processing or cooking, hot meal and dessert total of 26 samples); (II) equipment (refrigerator, cutting board, gastronomical tank, blender, cutter and vegetable processor - total of 33 samples); and (III) surfaces (stainless steel bench - total of 7 samples). Before distribution of lunch in each food service, we collected aseptically $25 \mathrm{~g}$ of each food in sterile plastic bag and stored under refrigeration until the time of analysis. Samples of equipment and surfaces were collected by swab smearing $\left(50 \mathrm{~cm}^{2}\right)$, moistened in saline $(0.85 \%)$. At the time of sampling, all points had been cleaned/sanitized in accordance with the parameters of each food service. In the absence of any of these items, the collection point was deleted. Material from the hands and nasal cavities of 21 food handlers ( 3 handlers from each food service) was collected using a swab that was moistened with saline $(0.85 \%)$, transported in Stuart medium (Laborclin) and used for Staphylococcus sp. enumeration. We analyzed the drinkability of the water used for the sanitization of salads. This research was conducted according to ethical principles and was approved by the Ethics Council from the Federal University of Rio Grande do Sul (Brasil, 1996).

\section{Microbiological analyses}

The dilution and homogenization of the samples as well as the analysis and identification of thermotolerant coliforms and Staphylococcus sp. were performed according to the Food and Drug Administration guidelines (USFDA, 2012). The species of Staphylococcus isolates were identified by Gram staining, catalase testing, coagulase testing, growth on mannitol salt agar, anaerobic growth on mannitol, hemolysis, pigment, Voges-Proskauer test, nitrate, fermentation of maltose and mannitol, urease, oxidase, growth at $15{ }^{\circ} \mathrm{C}, 45^{\circ} \mathrm{C}$ and in the presence of $15 \%$ $\mathrm{NaCl}$ (Cohen, 1968; Macfaddin, 2000). Water (100 mL) was analyzed by cultivation in Hicoliforme broth (Himedia), with prior inactivation of chlorine by adding sodium thiosulfate $(10 \%)$. All isolates were maintained in brain heart infusion broth (Himedia) with $25 \%$ glycerol and stored at $-20{ }^{\circ} \mathrm{C}$.

\section{Parameters for the microbiological analysis}

The results of the analyses were compared to the criteria described in the Technical Regulation on Microbiological Standards for Foods of the National Agency for Sanitary Vigilance Committee (Brasil, 2001). The study considered item 22 , specific to ready-to-eat meals, produced by food services or similar, where the presence of coagulase-positive Staphylococci (CoPS) is considered non-compliant. The evaluation of water quality was guided by Ordinance No. 2914/11 of the Brazilian Ministry of Health that determines the absence of thermotolerant coliforms and E. coli in $100 \mathrm{~mL}$ of water (Brasil, 2011). For the analysis of surfaces and equipment, the standards of the Pan American Health Organization (PAHO) were considered, which state that up to 49 colony-forming units per square centimeter is considered as a regular hygiene condition (Moreno, 1982).

\section{Detection of enterotoxin genes in the Staphylococcus sp. strains}

All strains of Staphylococcus sp. were subjected to polymerase chain reaction (PCR) for the presence of genes encoding the classical SE (sea, seb, sec, sed, and see). PCR reactions were performed in a final volume of $25 \mu \mathrm{L}$ : $1.5 \mathrm{mM} \mathrm{MgCl}, 0.2 \mathrm{mM}$ each dNTP, $0.2 \mathrm{mM}$ of each primer, $1 \mathrm{U}$ Taq polymerase (Promega), $10 \mathrm{ng}$ of DNA in a thermocycler Master Cycler Personal. The reaction was incubated for: 5 min at $94{ }^{\circ} \mathrm{C}$ followed by 30 cycles of $1 \mathrm{~min}$ at $94{ }^{\circ} \mathrm{C}, 1 \mathrm{~min}$ at the annealing temperature according to Table $1,1 \mathrm{~min}$ at $72{ }^{\circ} \mathrm{C}$ and a final cycle of $5 \mathrm{~min}$ at $72{ }^{\circ} \mathrm{C}$. To confirm the absence of inhibitors in the PCR reaction, all negative reactions for some SE genes were subjected to a new PCR reaction with primers detecting the $16 \mathrm{~S}$ rRNAprokaryote gene ( $8 \mathrm{f}$ and $925 \mathrm{r}$ ) described by Liu et al. (1997). The PCR products were visualized as described elsewhere (Sambrook and Russel, 2001). Sterile ultrapure water (Milli-Q) was used instead of DNA as a negative control. S. aureus ATCCs 13565 (sea), 14458 (seb), 19095 (sec), 23235 (sed) and 21664 (see) were used as positive controls.

\section{Results}

\section{Water analysis}

The water samples showed no thermotolerant coliforms or E. coli. The seven food services evaluated in this study used only water that was treated and distributed by the Municipal Water and Sewer Systems of Porto Alegre. 
Table 1 - Nucleotide sequences, annealing temperature and expected size of the PCR products for Staphylococci enterotoxins.

\begin{tabular}{|c|c|c|c|c|}
\hline Gene & Primer & Nucleotide sequence $\left(5^{\prime}-3^{\prime}\right)^{*}$ & Annealing temperature $\left({ }^{\circ} \mathrm{C}\right)$ & Amplicon (bp) \\
\hline \multirow[t]{2}{*}{ sea } & $\operatorname{sea}_{1}$ & GGTTATCAATGTGCGGGTGG & 56 & 102 \\
\hline & $\mathrm{sea}_{2}$ & CGGCACTTTTTTCTCTTCGG & & \\
\hline \multirow[t]{2}{*}{ seb } & $s e b_{1}$ & GTATGGTGGTGTAACTGAGC & 54 & 164 \\
\hline & $s e b_{2}$ & CCAAATAGTGACGAGTTAGG & & \\
\hline \multirow[t]{2}{*}{$\sec$} & $\sec _{1}$ & AGATGAAGTAGTTGATGTGTATGG & 58.5 & 451 \\
\hline & $\sec _{2}$ & CACACTTTTAGAATCAACCG & & \\
\hline \multirow[t]{2}{*}{ sed } & $\operatorname{sed}_{1}$ & CCAATAATAGGAGAAAATAAAAG & 49 & 278 \\
\hline & $\operatorname{sed}_{2}$ & ATTGGTATTTTTTTTCGTTC & & \\
\hline \multirow[t]{2}{*}{ see } & see $_{1}$ & AGGTTTTTTCACAGGTCATCC & 53 & 209 \\
\hline & $\mathrm{see}_{2}$ & CTTTTTTTTCTTCGGTCAATC & & \\
\hline
\end{tabular}

Legend: 1, primer forward; 2 , primer reverse; bp, base pairs; ${ }^{\circ} \mathrm{C}$, Celsius degrees; *, nucleotide sequences described by Mehrotra et al. (2000).

\section{Analysis of thermotolerant coliforms and} Staphylococcus sp.

In an overall evaluation of foods, equipment and surfaces, it was observed that $60.6 \%$ of the points analyzed showed thermotolerant coliforms counts above the recommended (Table 2).

All foods analyzed showed minimum number of $\mathrm{CoPs}$, and these parameters are within of the standards set by Brazilian legislation. Of the 108 sampling points analyzed, 121 strains were distributed between 26 different species of Staphylococcus sp. (15 strains from foods, 36 from equipment/surfaces, 37 and 33 from hands and nasal cavities of handlers, respectively). Among these strains, 105 were CoNS and 16 were CoPS. All of the CoPS were isolated from food handlers. All species isolated from foods (Table 3) were identified as CoNS. S. epidermidis was the most common species in foods, although it was not found in any of the equipment or surfaces analyzed. Thirty-six CoNS were isolated from equipment and surfaces, and 13 different species were identified. The species that was most frequently isolated from hands ( 9 of 37 isolates) and from the nasal cavities (14 of 33) was also S. epidermidis. Among all of the isolates from hands, only four were CoPS, represented by Staphylococcus hyicus (1 strain), S. lutrae (1 strain) and S. schleiferi (2 strains). Among the Staphylococcus $\mathrm{sp}$. isolated from the nasal cavities, 17 were CoPS, and the second most common species was $S$. schleiferi (10 out of 33 isolates). Among all handlers analyzed, nine were carriers of Staphylococcus sp. on their hands, and six harbored two or three different species. While twelve of the handlers showed Staphylococcus sp. in the nasal cavity, only three handlers were carriers of two different species in the same sampling.

\section{Analysis of Staphylococcal enterotoxin}

The gene $s e b$ was the most prevalent, either alone $(19.8 \%)$ or concomitant with other toxin(s) gene(s) (Table 4).

Table 2 - Compliance of food services regarding the microbiological limits for thermotolerant coliforms.

\begin{tabular}{|c|c|c|c|c|c|c|c|c|c|c|c|}
\hline \multirow[t]{2}{*}{ FS } & \multicolumn{2}{|c|}{ Salad } & \multirow[t]{2}{*}{ Hot meal } & \multirow[t]{2}{*}{ Dessert } & \multirow[t]{2}{*}{ S. bench } & \multirow[t]{2}{*}{ V. cutter } & \multirow[t]{2}{*}{ Blender } & \multirow[t]{2}{*}{ G.T. } & \multirow[t]{2}{*}{ C. board } & \multirow[t]{2}{*}{ V. processor } & \multirow[t]{2}{*}{ Refrig } \\
\hline & A & B & & & & & & & & & \\
\hline 1 & $\mathrm{n}$ & + & - & + & - & - & - & $\mathrm{n}$ & - & - & - \\
\hline 2 & + & + & + & - & - & - & - & $\mathrm{n}$ & - & - & + \\
\hline 3 & + & + & + & + & - & $\mathrm{n}$ & - & + & - & + & - \\
\hline 4 & - & - & + & - & - & - & $\mathrm{n}$ & - & - & $\mathrm{n}$ & + \\
\hline 5 & + & - & + & $\mathrm{n}$ & - & $\mathrm{n}$ & $\mathrm{n}$ & + & + & - & + \\
\hline 6 & - & + & - & + & + & + & $\mathrm{n}$ & - & - & - & - \\
\hline 7 & + & + & - & - & - & - & - & $\mathrm{n}$ & - & - & + \\
\hline
\end{tabular}

Legend: FS, food service; Salad A, raw salad; Salad B, processed salad; S. bench, stainless steel bench; V. cutter, vegetable cutter; G.T., gastronomic tank; C. board, cutting board; V. processor, vegetable processor; Refrig., refrigerator; n, inexistent equipment or food in food service; +, compliant; -, non-compliant. 
Table 3 - Staphylococcus sp. isolated from foods, equipment, surfaces and food handlers of food services.

\begin{tabular}{|c|c|c|c|}
\hline Species & Coag.1 & Source (n. of isolates) & n. of isolates \\
\hline S. arlattae & - & Food (3); Food handler - hand (2) & 5 \\
\hline S. aureus & + & Food handler - nose (1) & 1 \\
\hline S. auricularis & - & Food (1); Food handler - hand (2), nose (1) & 4 \\
\hline S. capitis & - & Equipment (1) & 1 \\
\hline S. caprae & - & Food handler - hand (5) & 5 \\
\hline S. carnosus & - & Food (1); Equipment (1); Food handler - hand (1) & 3 \\
\hline S. caseolyticus & - & Equipment/surface (4) & 4 \\
\hline S. chromogenes & - & Food (1); Equipment (2) & 3 \\
\hline S. cohnii sub. urealyticus & - & Food handler - hand (1) & 1 \\
\hline S. epidermidis & - & Food (5); Food handler - hand (9), nose (14) & 28 \\
\hline S. equorum sub. equorum & - & Equipment (1) & 1 \\
\hline S. gallinarum & - & Food (1); Food handler - hand (1) & 2 \\
\hline S. haemolyticus & - & Food (1); Equipment/surface (5) & 6 \\
\hline S. hominis & - & Equipment (5); Food handler - hand (4) & 9 \\
\hline S. hyicus & - & Food handler - hand (1), nose (4) & 5 \\
\hline S. hyicus-chromogenes & - & Food handler - hand (1) & 1 \\
\hline S. intermedius & + & Food handler - nose (2) & 2 \\
\hline S. lutrae & + & Food handler - hand (1) & 1 \\
\hline S. pasteuri & - & Food (1); Equipment (1); Food handler - hand (2), nose (1) & 5 \\
\hline S. saccharolyticus & - & Equipment (5) & 5 \\
\hline S. saprophyticus & - & Equipment/ surface (3); Food handler - hand (4) & 7 \\
\hline S. schleiferi & + & Food handler - hand (2), nose (10) & 12 \\
\hline S. simiae & - & Food handler - hand (1) & 1 \\
\hline S. simulans & - & Food (1); Equipment (4) & 5 \\
\hline S. vitulinus & - & Equipment (3) & 3 \\
\hline S. warneri & - & Equipment (1) & 1 \\
\hline Total & & & 121 \\
\hline
\end{tabular}

Legend: 1, coagulase; -, coagulase-negative Staphylococci; +, coagulase-positive Staphylococci; n., number.

The gene encoding seb was commonly found in both CoPS (29.2\%) and CoNS (70.8\%). This study revealed twelve different genotypes, consisting of four genotypes with single genes (sea, seb, sec e sed), six genotypes with combinations of two genes (sea+seb; sea+sec; seb+sec; seb+sed; seb+see; sed + see) and two genotypes with three genes (sea+seb+sed; seb+sec+sed). The enterotoxin E gene was present only in combination with another enterotoxin, rather than forming an individual genotype. Among the 121 Staphylococcus sp. tested in this study, 57 (47.1\%) were positive for any of the classical SE genes. Eighteen of the 26 species identified were positive for any of the SE genes. The species $S$. aureus (1), S. capitis (1), S. cohnii subspecies urealyticus (1), S. equorum subspecies equorum (1), $S$. lutrae (1), S. intermedius (2), S. simiae (1) and S. vitulinus
(3) were negative for the presence of the genes tested. The genotype sea+seb are present in two strains of Staphylococcus sp. isolated from foods (Table 5). In contrast, among isolates of equipment, surfaces and handlers, the seb genotype was predominant.

\section{Discussion}

As no thermotolerant coliforms were found after the microbiological analysis of the water used by the food services, it was classified as satisfactory. This is a very important point since it can act as a vehicle for the transmission of pathogens and spoilage agents (WHO, 2005). Foods that presented results from non-compliance due to high count thermotolerant coliforms were those who had added some 
Table 4 - Genotypic profile of the enterotoxins genes in Staphylococcus $\mathrm{sp}$. isolates from the food services.

\begin{tabular}{lc}
\hline Genotype & Number of isolates positive for genotypes (\%) \\
\hline sea & $4(7.0 \%)$ \\
seb & $24(42.1 \%)$ \\
sec & $1(1.7 \%)$ \\
sed & $6(10.5 \%)$ \\
sea + seb & $5(8.8 \%)$ \\
sea + sec & $2(3.5 \%)$ \\
seb+sec & $5(8.8 \%)$ \\
seb+sed & $4(7.0 \%)$ \\
seb+see & $1(1.7 \%)$ \\
sed + see & $1(1.7 \%)$ \\
sea + seb+sed & $1(1.7 \%)$ \\
seb+sec+sed & $3(5.3 \%)$ \\
Total & $57(100 \%)$ \\
\hline
\end{tabular}

Legend: (\%) percentage; sea, seb, sec, sed, see, gene of Staphylococci enterotoxin A, B, C, D and E, respectively.

ingredients after cooking, suggesting post-processing contamination. This suggests a failure in the use of good hygienic practices and in the quality control of raw materials. The high percentage of poor sanitary conditions of the surfaces and equipment of food services is alarming. It is known that equipment and countertops can provide conditions for the growth of microorganisms on their surfaces forming biofilms, as well as the possibility for further cross contamination (Legnani et al., 2004; Meira et al., 2012; Trinetta et al., 2012). In addition, the cross-contamination, post-processing, could be the explanation for at least $30 \%$ of the food analyzed in this study having levels of thermotolerant coliforms above the acceptable levels.

Considering only the analysis of Staphylococcus sp. and the Brazilian legislation, the results of this study showed that all foods produced by food services were in agreement with that legislation (Brasil, 2011). This legislation determines only the investigation of CoPS in foods because they are producers of toxins that are of considerable risk for human health. CoNS possessing SE genes have been isolated from foods by other authors, although they have not yet been identified as causative agents of food poisoning (Rode et al., 2007; Zell et al., 2008). So far, in Brazil, studies searching for the presence of Staphylococcus sp. in foods produced by food services were not described. However, some studies showed the presence of Staphylococcus sp. in many foods (Aragon et al., 2007; André et al., 2008; Rall et al., 2008, 2010a; Borelli et al., 2011; Oliveira et al., 2011).

Equipment and surfaces can accommodate a diverse microbiota. In the food services this can be influenced by contact with food (raw or processed), food handlers and by the processes of cleaning. Equipment and poorly sanitized environments may contain organic matter, which, combined with convenient extrinsic factors, can provide favorable conditions for the growth of microorganisms (Rode et al., 2007). Also, the contaminated equipment could be the

Table 5 - Enterotoxin genes found in Staphylococcus sp. isolates from the food services.

\begin{tabular}{|c|c|c|c|c|}
\hline \multirow[t]{3}{*}{ Gene of enterotoxins ${ }^{1}$} & \multicolumn{4}{|c|}{ Source } \\
\hline & \multirow[t]{2}{*}{ Food $(26)^{2}$} & \multirow[t]{2}{*}{ Equipment/surface $(40)^{2}$} & \multicolumn{2}{|c|}{ Food handler $(21)^{2}$} \\
\hline & & & Hand & Nasal cavity \\
\hline sea & - & $2(5 \%)$ & $1(4.8 \%)$ & $1(4.8 \%)$ \\
\hline seb & $1(3.8 \%)$ & $5(12.5 \%)$ & $5(23 \%)$ & $13(62 \%)$ \\
\hline $\mathrm{sec}$ & $1(3.8 \%)$ & - & - & - \\
\hline sed & - & $2(5 \%)$ & $4(19 \%)$ & - \\
\hline see & - & - & - & - \\
\hline sea+seb & $2(7.7 \%)$ & $2(5 \%)$ & $1(4.8 \%)$ & - \\
\hline sea+sec & - & $1(2.5 \%)$ & $1(4.8 \%)$ & - \\
\hline$s e b+s e c$ & $1(3.8 \%)$ & $1(2.5 \%)$ & $3(14 \%)$ & - \\
\hline seb+sed & - & $1(2.5 \%)$ & $3(14 \%)$ & - \\
\hline seb+see & - & $1(2.5 \%)$ & - & - \\
\hline sed + see & - & $1(2.5 \%)$ & - & - \\
\hline sea+seb+sed & - & $1(2.5 \%)$ & - & - \\
\hline seb+sec+sed & - & - & $2(9.5 \%)$ & $1(4.8 \%)$ \\
\hline
\end{tabular}

Legend: 1, sea, seb, sec, sed, see, gene of Staphylococcal enterotoxin A, B, C, D and E, respectively; 2, Number of samples; (), percentage of presence of the gene; -: absence. 
source of microorganisms for foods prepared with them (Meldrum et al., 2009; Meira et al., 2012). With regard to the Staphylococcus sp. isolated in this study, except for $S$. caseolitycus, which is commonly found in dairy products, all other isolated species from equipment and surfaces may be part of human microbiota (Cohen, 1986; Bes and Brun, 2012). The handlers' hands can be vehicles of contamination, so care with personal hygiene is essential in the production of meals (Shojaei et al., 2006; Rodriguez et al., 2011). In this study it was also observed that the same handler could accommodate more than one species in their microbiota, as was also observed by other authors (Acco et al., 2003; André et al., 2008).

The most common gene in Staphylococcus sp. identified from food services and foods was seb. SEB is one of the most potent toxins and the expression of that gene in food can be a danger to the health of the customers (Ahanotu et al., 2006, Sospedra et al., 2012). The prevalence of SE genes in foods varies and depends on regional and human factors. Their frequency in foods has been described in other studies and the rate was variable between them (Rall et al., 2008, 2010b; Pelisser et al., 2009; Borelli et al., 2011; Wang et al., 2013). In this study, 33\% of the Staphylococcus sp. isolated from foods harbored one or two SE genes.

Thus, it was observed that $61.5 \%$ and $100 \%$ of the food produced by food services in Porto Alegre showed counts of thermotolerant coliforms and Staphylococcus sp., respectively, which are within the limits defined by Brazilian legislation (Brasil, 2001). This result of compliance does not consider the wider dissemination of CoNS in food services, or the toxigenic potential of these isolates. It was observed that the sanitary conditions of equipment and surfaces were inadequate $(75 \%)$ for the production of meals; the enterotoxin B gene was the most prevalent among the Staphylococcus sp. evaluated. These results showed a risk to the customers of food services when exposed to food produced with inadequate hygiene practices and possessing thermotolerant coliforms and Staphylococcus sp. isolates with toxigenic potential. Thus, it is evident the necessity of the implementation and constant monitoring of programs of quality control in food services.

\section{Acknowledgments}

The authors thank the food services who participated in this research. We also thank the Federal Project REUNI and to CAPES / PROF for the financial resources.

\section{References}

Acco M, Ferreira FS, Henriques JAP, Tondo EC (2003) Identification of multiple strains of Staphylococcus aureus colonizing nasal mucosa of food handlers. Food Microbiol 20:489493.

Ahanotu E, Alvelo-Ceron D, Ravita T, Gaunt E (2006) Staphylococcal enterotoxin $\mathrm{B}$ as a biological weapon: recognition, management, and surveillance of Staphylococcal enterotoxin. Appl Biosaf 11:120-126.

André MCDPB, Campos MRH, Borges LJ, Kipnis A, Pimenta FC, Serafini AB (2008) Comparison of Staphylococcus aureus isolates from food handlers, raw bovine milk and Minas Frescal cheese by antibiogram and pulsed-field gel electrophoresis following SmaI digestion. Food Control 19:200-207.

Aragon-Alegro LC, Konta EM, Suzuki K, Silva MG, Júnior AF, Rall R, Rall VLM (2007) Occurrence of coagulase-positive Staphylococcus in various food products commercialized in Botucatu, SP, Brazil and detection of toxins from food and isolated strains. Food Control 18:630-634.

Balaban N, Rasooly A (2000) Staphylococcal enterotoxins. Int J Food Microbiol 61:1-10.

Bes M, Brun Y (2002) Staphylococcus: actualites taxonomiques et identification. Rev Fr Lab 343:23-30.

Borelli BM, Lacerda ICA, Brandão LR, Vianna CR, Ferreira MC, Gomes FCO, Carmo LS, Heneine LGD, Rosa CA (2011) Identification of Staphylococcus spp. isolated during the ripening process of a traditional Minas cheese. Arq Bras Med Vet Zootec 63:481-487.

Brasil (1996) Resolution No. 196. Guidelines and Standards for Research Involving Humans. National Health Council. Available at: http://www.bioetica.ufrgs.br/res19696.htm. Accessed 10 March 2008

Brasil (2001) Resolution No 12 of 02 january 2001. Technical Regulation on microbiological standards for food. National Agency for Sanitary Vigilance. Available at: http://www.anvisa.gov.br/legis/resol/12_01rdc.htm. Accessed 21 January 2011.

Brasil (2011) Dados epidemiológicos-DTA período de 2010 a 2011. Ministério da Saúde. Available at: http://portal.saude.gov.br/portal/arquivos/pdf/dados_epidemiologicos.pdf. Accessed 23 July 2012.

Brasil (2011) Ordinance No. 2914 of 12 december 2011. Sets forth the procedures for control and surveillance of water quality for human consumption and its potability standards. National Agency for Sanitary Vigilance. Available at: http://bvsms.saude.gov.br/bvs/saudelegis/gm/2011/prt2914 _12_12_2011.html. Accessed 06 September 2012.

Cohen JO, (1986) Differentiation of the genus Staphylococcus from other genera. In: Sneath, P.H.A., Mair, N.S., Sharpe, M.E., Holt, J.G. (eds) Bergeys Nanual of Systematic Bacteriology. New York, pp 1015-1035.

Food and Drug Administration. 2004. Produce safety from production to consumption: 2004 action plan to minimize foodborne illness associated with fresh produce consumption. Available at: http://www.fda.gov/Food/FoodborneIllnessContaminants/ BuyStoreServeSafeFood/ucm129487.htm. Accessed 05 july 2010.

Food and Drug Administration. 2012. Staphylococcus aureus. Available at: http://www.fda.gov/Food/FoodScienceResearch/Laborator yMethods/ucm071429.htm. Accessed 05 july 2010.

Legnani P, Leoni E, Berveglieri M, Mirolo G, Alvaro N (2004) Hygienic control of mass catering establishments, microbiological monitoring of food and equipment. Food control 15:205-211. 
Liu WT, Marsh TL, Cheng H, Forney LJ (1997) Characterization of microbial diversity by determining terminal Restriction Fragment Length Polymorphisms of genes encoding 16S rRNA. Appl Environ Microbiol 63:4516-4522.

Losasso C, Cibin V, Cappa V, Roccato A, Vanzo A, Andrighetto I, Ricci A (2012) Food safety and nutrition: Improving consumer behavior. Food Control 26:252-258.

Macfaddin JF (2000) Biochemical testes for identification of medical bacteria. Lippincott Williams \& Wilkins. Philadelphia.

Mehrotra M, Wang G, Johnson WM (2000) Multiplex PCR for detection of genes for Staphylococcus aureus enterotoxins, exfoliative toxins, toxic shock syndrome toxin 1, and methicillin resistance. J Clin Microbiol 38:1032-1035.

Meira QGS, Barbosa IM, Athayde AJAA, Siqueira-Júnior JP, Souza EL (2012) Influence of temperature and surface kind on biofilm formation by Staphylococcus aureus from foodcontact surfaces and sensitivity to sanitizers. Food Control 25:469-475.

Meldrum RJ, Little CL, Sagoo S, Mithani V, McLauchlin J, Pinna E (2009) Assessment of the microbiological safety of salad vegetables and sauces from kebab take-away restaurants in the United Kingdom. Food Microbiol 26:573-577.

Moreno LS (1982) Higiene de lá alimentación. Adeos, Barcelona.

Oliveira AM, Padovani CR, Miya NTN, Sant'Ana AS, Pereira JL (2011) High incidence of enterotoxin D producing Staphylococcus spp. in Brazilian cow's raw milk and its relation with coagulase and thermonuclease enzymes. Foodborne Pathog Dis 8:159-163.

Pelisser MR, Klein CL, Ascoli KR, Zotti TR, Arisi ACM (2009) Occurrence of Staphylococcus aureus and multiplex PCR detection of classic enterotoxin genes in cheese and meat products. Braz J Microbiol 40:145-148.

Pereira V, Lopes C, Castro A, Silva J, Gibbs P, Teixeira P (2009) Characterization for enterotoxin production, virulence factors, and antibiotic susceptibility of Staphylococcus aureus isolates from various foods in Portugal. Food Microbiol 26:278-282.

Rall VLM, Sforcin JM, Augustini VCM, Watanabe MT, Fernandes Jr. A, Rall R, Silva MG, Araújo Jr JP (2010b) Detection of enterotoxin genes of Staphylococcus sp. isolated from nasal cavities and hands of food handlers. Braz J Microbiol 41:59-65.

Rall VLM, Sforcin JM, Deus MFR, Sousa DC, Camargo CH, Godinho NC, Galindo LA, Soares TCS, Araújo Jr. JP (2010a) Polymerase chain reaction detection of enterotoxins genes in coagulase-negative Staphylococci isolated from Brazilian minas cheese. Foodborne Pathog Dis 7:11211123.
Rall VLM, Vieira FP, Rall R, Vieitis RL, Fernandes Jr A, Candeias JMG, Cardoso KFG, Araújo Jr. JP (2008) PCR detection of staphylococcal enterotoxin genes in Staphylococcus aureus strains isolated from raw and pasteurized milk. Vet Microbiol 132:408-413.

Rode TM, Langsrud S, Holck A, Møretrø T (2007) Different patterns of biofilm formation in Staphylococcus aureus under food-related stress conditions. Int J Food Microbiol 116:372-383.

Rodriguez M, Valero A, Carrasco E, Pérez-Rodríguez F, Posada GD, Zurera G (2011) Hygienic conditions and microbiological status of chilled ready-to-eat products served in southern Spanish hospitals. Food Control 22:874-882.

Sambrook J, Russel DW (2001) Molecular Cloning. A Laboratory Manual. Cold Spring Harbor Laboratory Press, New York.

Shojaei H, Shooshtaripoor J, Amiri M (2006) Efficacy of simple hand-washing in reduction of microbial hand contamination of Iranian food handlers. Food Res Int 39:525-529.

Sospedra I, Marín R, Mañes J, Soriano JM (2012) Rapid whole protein quantification of staphylococcal enterotoxin $\mathrm{B}$ by liquid chromatography. Food Chem 133:163-166.

Trinetta V, Vaid R, Xu Q, Linton R, Morgan M (2012) Inactivation of Listeria monocytogenes on ready-to-eat food processing equipment by chlorine dioxide gas. Food Control 26:357-362.

Veras JF, Carmo LS, Tong LC, Shupp JW, Cummings C, Santos DA, Cerqueira MMOP, Cantini A, Nicoli JC, Jett M (2008) A study of the enterotoxigenicity of coagulase-negative and coagulase-positive staphylococcal isolates from food poisoning outbreaks in Minas Gerais. Brazil Int J Infect Dis 12:410-415

Wang X, Tao X, Xia X, Yang B, Xi M, Meng J, Zhang J, Xu B (2013) Staphylococcus aureus and methicillin-resistant Staphylococcus aureus in retail raw chicken in China. Food Control 29:103-106.

World Health Organization (2005) Guidelines for the control of shigellosis, including epidemics due to Shigella dysenteriae type 1 . World Health Organization. http://whqlibdoc.who.int/publications/2005/9241592330.pdf.

World Health Organization (2012) Prevention of foodborne disease: Five keys to safer food manual. World Health Organization. Available at: http://www.who.int/foodsafety/publications/consumer/flyer_keys_en.pdf. Accessed 05 may 2013.

Zell C, Resch M, Rosenstein R, Albrecht T, Hertel C, Götz F (2008) Characterization of toxin production of coagulasenegative staphylococci isolated from food and starter cultures. Int J Food Microbiol 127:246-251.

All the content of the journal, except where otherwise noted, is licensed under a Creative Commons License CC BY-NC. 